\section{Endelig en lærebok i epidemiologi og statistikk}

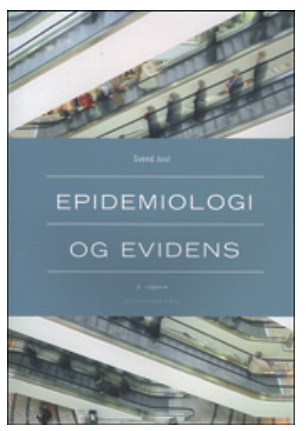

\section{Svend Juul} Epidemiologi og evidens

293 s, tab, ill. København: Munksgaard Danmark, 2012. Pris DKK 298

ISBN 978-87-628-1086-0

I Norge er jeg redd vårt fakultet ligger lengst «bakpå» når det gjelder systematisk innføring i metodefagene epidemiologi og biostatistikk i medisinstudiet. Det er mager trøst at flere av studentene får et visst kjennskap til fagene i arbeidet med hovedoppgaven i 5 . studieår, og at vi har gode utdanningsprogrammer for de som velger forskerlinjen, og på master- og ph.d.-nivå. I valg av anbefalt litteratur i grunnstudiet har vi også hatt et dilemma mellom et lite antall enkle innføringsbøker på norsk og de vanligste referansebøkene på engelsk. Det er neppe en løs påstand at flertallet av studenter ikke finner det bryet verdt å skaffe seg en lærebok i fagene og i stedet satser på forelesninger, notater og tidligere eksamensoppgaver.

Denne leser oppfatter derfor Epidemiologi og evidens som nær et Columbi egg i så måte. Det mest negative får være at det måtte et andre opplag til før jeg ble oppmerksom på den. Boken er skrevet på lettleselig dansk og kommer fra det utmerkede fagmiljøet ved universitetet i Århus. Et annet av mange fortrinn er at boken har en eneforfatter, noe som gir fremstillingen konsistens og flyt fra begynnelse til slutt. Boken har «alt» en student på dette nivået behøver, og mer til. Det siste sikter til behovet for å forstå og lære det uunnværlige samspillet mellom epidemiologi og medisinsk statistikk. «Formlene» har alltid vært en sperre for mange.

Boken er inndelt i kapitler på en logisk måte - fra det basale til det mer avanserte stoffet, bl.a. grunnleggende mål, hypoteser og evidens, assosiasjonsmål, design, innhenting av informasjon, seleksjon og effektmodifikasjon og konfundering. Studenter med mer klinisk legning vil føle seg mest fortrolig med kapitlene om vurdering av behandlingseffekt, diagnostikk, evidensbasert medisin og screening. I andreutgaven er det kommet med et kapittel om helsetjenesteøkonomi. Det kan også leses med utbytte av norske studenter.

Kapitlene er problemorienterte og illustrert med eksempler og har referanser til så vel lærebøker som publiserte artikler. Vekten ligger på perinatal epidemiologi og kreftepidemiologi. Det er utarbeidet relevante øvinger til hvert kapittel, og regneoppgavene er først og fremst ment å belyse samspillet mellom «tvillingfagene» epidemiologi og statistikk. Forfatteren har lagt vekt på balansen mellom folkehelseperspektivet og klinisk evidensbasert medisin.

Det er fire appendikser: A. Flere statistiske redskaper, B. Statistiske tabeller, C. Svar på øvelsene og D. Et minileksikon. Det siste omfatter også mange gode oversettelser til dansk av engelske ord og uttrykk som dessverre har glidd inn som en integrert del av stammespråket. Det følger en personlig e-nøkkel med hvert eksemplar slik at boken kan lastes ned fra nettet i fulltekstformat.

Dette er en bok det er lett å bli glad i og enkelt å foreslå som lærebok for medisinstudentene og andre med behov som går ut over en enkel innføringsbok. Den holder det den lover i form av «...den information, man som kliniker behøver for at vurdere en videnskabelig artikel med epidemiologisk-statistiske briller, og den giver redskaberne til at omsætte forskningens resultater i en evidensbaseret praksis.»

\section{Geir W. Jacobsen}

Det medisinske fakultet

Norges teknisk-naturvitenskapelige universitet

\section{Kortfattet oversikt}

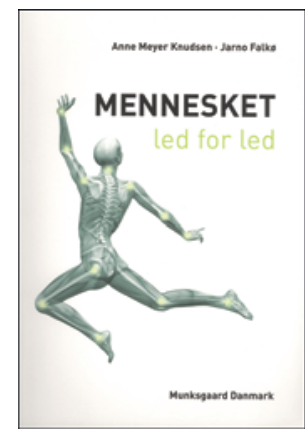

Anne Meyer Knudsen, Jarno Falkø

Mennesket - led for led

156 s, tab, ill. København: Munksgaard

Danmark, 2011. Pris DKK 185

ISBN 978-87-628-0990-1

Kompendier og lettfattelige læremidler er i vinden for tiden. Sett fra studentenes side kan det være fristende å bruke slike som en hjelp til å komme seg gjennom eksamen, men de gir neppe noen varig eller dypere forståelse av et medisinsk fagfelt eller problem. Dette heftet, skrevet på dansk, er ment å være «primært til studerende inden for fysioterapi, idræt, ergoterapi, medicin og sygepleje» - altså et ganske bredt spektrum av fag hvor nøyere kunnskap om bevegelsesapparatet er nødvendig.

Bakgrunnen til forfatterne fremgår ikke, men boken oppgis å være skrevet som en konsekvens av deres egne tidligere erfaringer med å forstå leddenes oppbygning og betydning for bevegelser. Under dette arbeidet har de følgelig konsultert en anatom og en fysioterapeut.

Forfatterne har gjort bruk av illustrasjoner fra et tredimensjonalt, engelsk computerprogram (Primal 3D Human Anatomy), og de har tegnet inn de nødvendige leddstrukturene - ligamenter, bindevevskapsler, synovialhinner, brusk etc. - på dette i form av enkle streker i forskjellige farger, men uten å ville gi forståelse av hvordan strukturen virkelig ser ut. Denne kombinasjonen av naturtro leddfremstilling sammen med symbolsk abstraksjon og fargekoder er faktisk ganske godt laget og gir leseren et inntrykk av det enkelte ledds bestanddeler.

Hvert ledd karakteriseres som type, med bevegelsesutslag i antall grader, tilhørende ligamenter, muskler og musklenes innervasjon, alt i skjematisk form som viser oss hvor synovialhinnen fester seg, hvordan den fibrøse kapselen går osv. Naturligvis innledes boken med en oversikt over ledd generelt: type, frihetsgrader, akser og bevegelsesplan. En kort litteraturliste hører også med.

En så kortfattet fremstilling må nødvendigvis ha mangler, og dem er det flere av. Verre er det kanskje at heftet inneholder unøyaktigheter (og et par småfeil), for eksempel at alarligamentene kun bremser hodets rotasjonsbevegelser (de tar del i alle bevegelser) eller at claviculas rotasjon ved heving og senkning av skulderen ikke nevnes. Kneleddet karakteriseres som et «modificeret hængselled», uten at dette svevende begrepet forklares nærmere. Jeg er derfor ikke ubetinget enig $i$ at boken «er dækkende både til indlæring og eksamenslæsningen». Så viktig som leddforståelsen er, både for den medisinske profesjonen og for fysioterapeutene især, kunne man nok ønske seg primærlitteratur med et annet og fyldigere innhold. Men som repetitorium, både før eksamen og kanskje også senere i profesjonell praksis, kan boken nok gjøre nytte.

\section{Per Holck}

Anatomisk avdeling

Institutt for medisinske basalfag

Universitetet i Oslo 